Original Research Paper

\title{
In vivo Efficacy of Murraya paniculata Leaf in Controlling Natural Helminthiasis in Goat
}

\author{
${ }^{1}$ Duangjai Boonkusol, ${ }^{1}$ Janejira Detraksa, ${ }^{1}$ Kansuda Duangsrikaew and ${ }^{2}$ Wuttipong Tongbai \\ ${ }^{1}$ Department of Biology, Faculty of Science and Technology, Thepsatri Rajabhat University, Lopburi, Thailand \\ ${ }^{2}$ Department of Biology, Faculty of Science, Srinakharinwirot University, Bangkok, Thailand
}

\author{
Article history \\ Received: 17-01-2019 \\ Revised: 29-03-2019 \\ Accepted: 30-04-2019 \\ Corresponding Author: \\ Duangjai Boonkusol \\ Department of Biology, \\ Faculty of Science and Technology, \\ Thepsatri Rajabhat University, \\ Lopburi, Thailand \\ Tel.: +66 899929368 \\ Email: ngamsomd@gmail.com
}

\begin{abstract}
This study investigated the in vivo effect of Murraya paniculata leaf on gastrointestinal nematodes reduction, growth rates and haematological changes of goats. Four experimental groups $(n=6)$ of goats naturally acquired gastrointestinal nematodes were control (GI) (untreated), positive control (GII) (treated with albendazole, $6 \mathrm{mg} / \mathrm{Kg} \mathrm{BW}$ ) and GIII and GIV treated with 5 and 10 $\mathrm{g} / \mathrm{Kg} \mathrm{BW}$ of $M$. paniculata leaves. Fecal samples collections were performed weekly for assessment of fecal egg count. Number of nematode eggs in goat feces (egg per gram; EPG) was determined from week 0 (pre-treatment) to week 8 (post-treatment) by modified McMaster egg counting technique. EPG values of GIV goats were significantly lower than that of the controls and those receiving the albendazole $(\mathrm{p}<0.05)$ at week 3 . GII goats showed highly effective at EPG reduction in 1-2 weeks after giving albendazole and then the efficiency decreased until the end of the experiment. The effect of M. paniculata leaves on growth rate was studied by examining goat weight on days $0,30,60$ and 90. GIV group revealed significantly higher weight change than other groups $(p<0.05)$. The feeding of $M$. paniculata leaves at different levels did not affect on haematological parameters, glucose, total protein, urea, albumin and globulin of goats. It was found that values of the haematological parameters were within the range of the standard values. Compound analysis of $M$. paniculata leaves revealed that $M$. paniculata leaves contained higher protein content than grass and the protein content was closed to the meal concentrate. This corresponds to the best growth rates of GIV goats. The results demonstrated that $M$. paniculata leaves reduce the gastrointestinal nematode eggs of goats efficiently, safely and environment-friendly.
\end{abstract}

Keywords: Orange Jessamine Leaf, Herbal Anthelmintics, Gastrointestinal Nematode, Goat, In vivo Test

\section{Introduction}

Goat farming is an interesting source of earnings for goat shepherd in Lopburi province, Thailand. Helminthiasis is one of the most common setbacks in production and reproductive performance of livestock (Kochapakdee, 1991). Boonkusol (2016) studied prevalence of gastrointestinal parasites in goats at different age and sex in six districts of Lopburi province and reported that strongyle-type eggs, Trichuris spp. eggs and coccidian oocysts were found with prevalence rates of $67.2 \%, 4.4 \% 78.8 \%$, respectively. High infection of gastrointernal parasites were observed in goats at age of 13 year $(57.3 \%)$ and $<1$ year $(36.9 \%)$. The lowest infection was $>3$ years old goats $(5.8 \%)$. Most of the effects caused by helminth parasitoses were unnoticed due to sub-clinical or chronic character of the diseases (Dawo and Tibo,
2005). Antibiotics use in the diseases control is no longer sustainable because of high levels of antibiotics resistance, high cost and residue problem (Waller, 2006).

The option of herbal anthelmintics has provided an important and viable alternative to control and treat these helminthic infections (Waller, 2001). Studies of anthelmintic activity of many plants are still in large scientific interest despite widespread use of chemicals in modern clinical practices as anthelmintics (Githiori et al., 2006; Jabbar et al., 2007; Eguale et al., 2011). Murraya paniculata is one of many medicinal plants used by traditional communities in Thailand. Medicinal plants are use in animal feeds as growth promoters. They reveal a major role as antioxidant, antibacterial, anthelmintic and anticoccidial without residual effects. Murraya paniculata, orange jessamine, leaf was reported to have 
in vitro anthelmintic activity (Boonkusol, 2017), but there was no report of vivo antihelminthic activity.

Reduction of fecal egg counts with time is an indication of in vivo anthelmintic activity. The therapeutic assessment was based on the estimation of production data (body weight (BW), Body Weight Gain (BWG) and helminthes eggs reduction, indicating anthelmintic activity (Burke et al., 2009; Deore and Khadabadi, 2010).

Since no report has addressed the in vivo efficacy of the $M$. paniculata leaf in controlling natural helminthosis, the present study was conducted taking the above view into consideration with the aim to assess $M$. paniculata efficacy in controlling natural helminthosis. The therapeutic assessment was based on nematodes egg reduction body weight, body weight gain and haematological parameters, indicating antihelminthic activity.

\section{Materials and Methods}

\section{Collection of $M$. paniculata Leaves}

Leaves of $M$. paniculata were collected from Patthana Nikhom District, Lopburi province, Thailand were selected, on the basis of their documented anthelmintic properties, according to report of Boonkusol (2017). The leaves of M. paniculata were harvested during the period from November 2017 to January 2018 and feed fresh to the goats.

\section{Experimental Goats}

All experimental goats were cross-bred goats (native and Anglo-Nubian breeds). Twenty-four goats (males 13 years of age) raised in Phatthana Nikhom districts, Lopburi province, Thailand were selected for the study expecting to be nematodes infected goats and were labeled by number tag. They were allowed to graze freely in boundary and feed concentrates as supplement. Mineral licks and water were obtainable ad libitum. Their fresh fecal samples were determined Egg count Per Gram (EPG) to confirm that the animals were naturally infected with nematodes. The goats were weighed using an overhead spring balance (0-50 kg scale), fresh fecal samples collected directly via rectum into clean, capped, air-tight plastic sample containers ready for EPG counting.

\section{Treatments}

The experimental goats were randomly divided into four groups $(n=6)$ : GI (untreated), GII (treated orally with albendazole, $6.0 \mathrm{mg} / \mathrm{Kg} \mathrm{BW} \times 1$ dose) and GIII and GIV treated orally with 5.0 and $10.0 \mathrm{~g} / \mathrm{Kg} \mathrm{BW}$ of $M$. paniculata leaves for 10 days. Fresh fecal samples were obtained from the goats before treatment (week 0) and 1st to 8th (week) post-treatment. The samples were transported in an ice box to laboratory for immediate analysis.

Blood collections from jugular vein of each goat were performed before the treatment (day 0) and post treatment at 30th, 60th and 90th day. At the date, blood collection was performed at 9 a.m. before meal and 3 p.m. after meal for 6 hours. Various hematological parameters (glucose, urea, total protein, albumin and globulin) were measured.

Individual live body weight of experimental goat was examined before the treatment (day 0 ) and post treatment at 30th, 60th and 90th day of experimental period using an overhead spring balance (0-50 kg scale).

\section{Fecal Egg Count}

The intensity of egg per gram of feces (EPG) was determined by modified Mc Master egg counting technique. Fecal suspension was prepared using one gram of fecal sample in $14 \mathrm{~mL}$ saturated salt solution. Samples were sieved through tea strainer and transferred into test tube. Mc Master egg counting chamber of was charged and eggs of gastrointestinal nematodes were counted under $10 \mathrm{X}$ magnification of light microscope. EPG was calculated as follows:

$$
\begin{aligned}
& \text { Egg per gram }(E P G)=\text { Number of eggs in the } \\
& \text { chamber } \times 50
\end{aligned}
$$

Eggs per gram of feces were recorded. Efficacy of different treatment was examined by fecal egg count reduction following the formula below:

$$
\text { Efficacy }=\frac{(E P G \text { pre }- \text { treatment }-E P G \text { post }- \text { treatment }}{E P G \text { pre }- \text { treatment }} \times 100
$$

\section{Diets Analysis}

Goat diets in this study, M. paniculata leaves, grass and meal concentrate, were analysed to determine the crude protein and moisture by proximate analysis (AOAC, 1990) and crude fiber by Van Soest methods (1987).

\section{Data Analysis}

Data analysis was performed using one-way analysis of variance (ANOVA), followed by post-hoc analysis (Dunnett's test) using statistical package programme. The significant difference level was $\mathrm{P}<0.05$.

\section{Results}

\section{Fecal Egg Count}

Fecal egg count and efficacy of M. paniculata leaves on reduction of gastrointestinal nematodes eggs were presented in Table 1. Albendazole and M. paniculata leaves showed a general positive in vivo anthelmintic activity compared to untreated control.

Significant $(p<0.05)$ reduction of EPG counts were observed in the 1 st to 4 th week following M. paniculata treated goats. On the other hand, EPG counts of untreated group (GI) were significantly $(p<0.05)$ increased up to the 8 th week. 
Table 1: Egg per gram (EPG) values of the treated and control groups pre and post administration of M. paniculata Mean number of egg per gram (\% Efficacy)

\begin{tabular}{lllll} 
& GI & GII & GIII & GIV \\
\hline week 0 & $2,632.91^{\mathrm{a}}$ & $2,766.26^{\mathrm{a}}$ & $2,966.29^{\mathrm{a}}$ & $2,798.81^{\mathrm{a}}$ \\
week 1 & $3,166.31^{\mathrm{a}}$ & $865.35(68.72)^{\mathrm{b}}$ & $2,732.93(7.87)^{\mathrm{c}}$ & $2,566.23(8.31)^{\mathrm{c}}$ \\
week 2 & $3,566.35^{\mathrm{a}}$ & $631.64(77.17)^{\mathrm{b}}$ & $2,298.55(22.51)^{\mathrm{c}}$ & $1,532.62(45.24)^{\mathrm{d}}$ \\
week 3 & $4,466.05^{\mathrm{a}}$ & $1,098.48(60.29)^{\mathrm{b}}$ & $2,066.12(30.35)^{\mathrm{c}}$ & $664.94(76.24)^{\mathrm{d}}$ \\
week 4 & $5,832.85^{\mathrm{a}}$ & $2,299.27(16.88)^{\mathrm{b}}$ & $2,498.67(15.76)^{\mathrm{b}}$ & $1,564.93(44.09)^{\mathrm{c}}$ \\
week 5 & $5,966.48^{\mathrm{a}}$ & $3,065.77(-10.83)^{\mathrm{b}}$ & $3,032.97(-2.25)^{\mathrm{b}}$ & $2,397.16(14.35)^{\mathrm{c}}$ \\
week 6 & $6,099.45^{\mathrm{a}}$ & $4,433.08(-60.26)^{\mathrm{b}}$ & $3,933.05(-32.59)^{\mathrm{b}}$ & $3,097.81(-10.68)^{\mathrm{c}}$ \\
week 7 & $6,599.49^{\mathrm{a}}$ & $5,566.17(-101.22)^{\mathrm{b}}$ & $4,333.08(-46.08)^{\mathrm{c}}$ & $3,564.95(-27.37)^{\mathrm{d}}$ \\
week 8 & $6,265.95^{\mathrm{a}}$ & $6,232.89(-125.32)^{\mathrm{a}}$ & $4,999.33(-68.54)^{\mathrm{b}}$ & $4,199.60(-50.05)^{\mathrm{b}}$ \\
\hline
\end{tabular}

$\overline{\mathrm{a}, \mathrm{b}, \mathrm{c}, \mathrm{d}}=$ Significant at $\mathrm{p}<0.05$ in the same raw

Table 2: Effect of $M$. paniculata leaf on body weight in goat

\begin{tabular}{|c|c|c|c|c|}
\hline & \multicolumn{4}{|c|}{ Mean of body weight $(\mathrm{kg})$} \\
\hline & GI & GII & GIII & GIV \\
\hline Day 0 & $20.27 \pm 1.10^{\mathrm{a}}$ & $20.47 \pm 2.00^{\mathrm{a}}$ & $20.90 \pm 4.77^{\mathrm{a}}$ & $20.50 \pm 2.87^{\mathrm{a}}$ \\
\hline Day 30 & $21.10 \pm 1.95^{\mathrm{a}}$ & $22.20 \pm 1.78^{\mathrm{ab}}$ & $22.40 \pm 5.39^{\mathrm{b}}$ & $21.97 \pm 3.67^{\mathrm{ab}}$ \\
\hline Day 60 & $21.20 \pm 1.87^{\mathrm{a}}$ & $22.97 \pm 1.50^{\mathrm{b}}$ & $23.60 \pm 4.85^{\mathrm{b}}$ & $21.13 \pm 2.99^{\mathrm{a}}$ \\
\hline Day 90 & $22.40 \pm 1.14^{\mathrm{a}}$ & $23.67 \pm 1.22^{\mathrm{b}}$ & $24.40 \pm 5.43^{\mathrm{b}}$ & $24.53 \pm 2.65^{\mathrm{b}}$ \\
\hline Change of BW $(\mathrm{kg})$ & $2.13 \pm 0.67^{\mathrm{a}}$ & $3.20 \pm 0.90^{\mathrm{a}}$ & $3.50 \pm 1.59^{\mathrm{b}}$ & $4.03 \pm 0.67^{\mathrm{c}}$ \\
\hline Growth rate (g/day) & $23.67 \pm 7.40^{\mathrm{a}}$ & $35.56 \pm 10.02^{\mathrm{a}}$ & $38.88 \pm 10.67^{\mathrm{b}}$ & $44.78 \pm 2.78^{\mathrm{c}}$ \\
\hline
\end{tabular}

The above values represent the mean \pm Standard Deviation (SD)

$a, b, c=$ Significant at $\mathrm{p}<0.05$ in the same column

Table 3: Blood glucose and urea level before and after feeding

\begin{tabular}{|c|c|c|c|c|}
\hline & \multicolumn{4}{|c|}{ Blood glucose $(\% \mathrm{mg})$ and urea $(\mathrm{mmol} / \mathrm{l})$ level } \\
\hline & GI & GII & GIII & GIV \\
\hline Glucose at before feeding & $52.00 \pm 1.00^{\mathrm{a}}$ & $50.37 \pm 0.12^{\mathrm{a}}$ & $57.60 \pm 0.20^{\mathrm{b}}$ & $51.58 \pm 0.68^{\mathrm{a}}$ \\
\hline Glucose at after feeding & $64.87 \pm 0.31^{\mathrm{a}}$ & $60.63 \pm 0.15^{\mathrm{a}}$ & $71.63 \pm 0.47^{b}$ & $60.00 \pm 1.05^{\mathrm{a}}$ \\
\hline Glucose changes & $12.87 \pm 0.95$ & $10.26 \pm 0.06$ & $14.03 \pm 0.55$ & $8.42 \pm 0.45$ \\
\hline Urea at before feeding & $21.65 \pm 0.52^{\mathrm{a}}$ & $19.93 \pm 0.06^{\mathrm{a}}$ & $23.84 \pm 0.69^{\mathrm{b}}$ & $26.29 \pm 0.12^{\mathrm{b}}$ \\
\hline Urea at after feeding & $23.32 \pm 0.08^{\mathrm{a}}$ & $22.28 \pm 0.13^{\mathrm{a}}$ & $26.13 \pm 0.45^{\mathrm{b}}$ & $28.60 \pm 0.30^{b}$ \\
\hline Urea changes & $1.67 \pm 0.58$ & $2.35 \pm 0.09$ & $2.29 \pm 0.48$ & $2.31 \pm 0.25$ \\
\hline
\end{tabular}

The above values represent the mean \pm Standard Deviation (SD)

$\mathrm{a}, \mathrm{b}=$ Significant at $\mathrm{p}<0.05$ in the same column of each parameter

There were significant $(\mathrm{P}<0.05)$ peaks efficacy for M. paniculata leaves at $5 \mathrm{~g} / \mathrm{kg} \mathrm{BW}$ and $10 \mathrm{~g} / \mathrm{kg} \mathrm{BW}$. The $10 \mathrm{~g} / \mathrm{kg}$ BW M. paniculata group produced efficacy of $76.24 \%$ at week 3 Post-Treatment (PT) followed by $5 \mathrm{~g} / \mathrm{kg} \mathrm{BW}$ group which gave $30.34 \%$ at week 3 PT while Albendazole gave $77.17 \%$ at week 2 PT. M. paniculata showed time and dose-dependent in vivo anthelmintic effect.

\section{Body Weights}

Changes in the Body Weights (BW) of the goats were recorded in Table 2. There were significant $(\mathrm{P}<0.05) \mathrm{BW}$ changes of the goats treated with $M$. paniculata and Albendazole on day 90 PT compared with day 0. All groups had significant $(\mathrm{P}<0.05)$ increases in their mean BW by day 90 PT except the untreated group (GI).
The result showed the best growth rate of goats in GIV group. The daily growth rate and weight change rate were $44.78 \mathrm{~g} /$ day and $4.03 \mathrm{~kg}$, which was higher than that of other goats.

\section{Blood Parameters}

The results of the effect of $M$. paniculata leaf on different hematological parameters glucose, total protein, urea, albumin and globulin in goat blood were shown in Table 3 and 4 . The blood glucose levels before and after feeding of all groups were found to be within the standard level range (50.0 to $75.0 \% \mathrm{mg}$ ) (Plumb, 1999). However, glucose level of GI and GII goats were found to be higher than GIII and GIV goats. It might result from GI and GII goats were fed with meal concentrate which is lower fiber diets than plant leaves, resulting in rapid fermentation and conversion to glucose in the blood. 
Table 4: Total protein, albumin and globulin level in blood of goats

Total protein, albumin and globulin $(\mathrm{g} / \mathrm{l})$

\begin{tabular}{lllll} 
& GI & GII & GII & GIV \\
\hline Total protein & $67.47 \pm 0.35 \mathrm{a}$ & $65.13 \pm 0.25 \mathrm{a}$ & $70.50 \pm 0.46 \mathrm{a}$ & $72.40 \pm 0.56 \mathrm{a}$ \\
Albumin & $35.13 \pm 0.42 \mathrm{a}$ & $36.20 \pm 0.36 \mathrm{a}$ & $33.03 \pm 0.31 \mathrm{a}$ & $32.83 \pm 0.25 \mathrm{a}$ \\
Globulin & $31.93 \pm 0.15 \mathrm{a}$ & $31.57 \pm 0.47 \mathrm{a}$ & $31.03 \pm 0.21 \mathrm{a}$ & $33.67 \pm 0.67 \mathrm{a}$ \\
\hline
\end{tabular}

The above values represent the mean \pm Standard Deviation (SD)

Table 5: Percentage of crude protein, crude fiber and moisture of goat diets

\begin{tabular}{llll}
\hline Experimental food & Crude protein $(\%)$ & Crude fiber $(\%)$ & Moisture $(\%)$ \\
\hline M. paniculata leaves & 12.34 & 23.34 & 57.81 \\
Grass & 8.48 & 41.62 & 64.77 \\
Meal concentrate & 16.30 & 13.18 & 66.27 \\
\hline
\end{tabular}

The blood urea levels before and after feeding of GIII and GIV goats were significantly higher than GI and GII goats, however, blood urea levels of all groups were within the standard level range (12.6 to $28.0 \mathrm{mmol} / \mathrm{l})$ (Plumb, 1999). The standard level range of total protein, albumin and globulin were 64.0-75.0 g/l (zircon, 1995), 27.0-39.0 g/l and 27.0-41.0 g/l (Plumb, 1999), respectively. In this study, the total blood protein (65.13$72.40 \mathrm{~g} / \mathrm{l})$, albumin (32.83-36.20 g/l) and globulin (31.03-33.67 g/l) were in in the standard range in all four groups and there were no statistically significant differences of them among groups. Albumin and globulin values were.

\section{Diets Analysis}

Compound analysis of goat diets, M. paniculata leaves, grass and meal concentrate (Table 5) revealed that $M$. paniculata leaves contained higher protein content than grass and the protein content was closed to the meal concentrate. The results showed that total protein content of $M$. paniculata leaves, grass and meal concentrate were $12.34 \%, 8.48 \%$ and $16.30 \%$, respectively. Fiber contents of $M$. paniculata leaves, grass and meal concentrate were $23.34 \%, 41.62 \%$ and $13.18 \%$, respectively. Moisture content of M. paniculata leaves, grass and meal concentrate were $57.81 \%, 64.77 \%$ and $66.27 \%$, respectively.

\section{Discussion}

In vivo anthelmintic results for $M$. paniculata leaves are being reported for the first time of conducting this study. The ingestion of $M$. paniculata leaves affected reduction of nematode eggs with efficacy of $76.19 \%$ (10 $\mathrm{g} / \mathrm{kg}$ BW M. paniculata leaves). M. paniculate leaves also improved body weight of goat. It provides an alternative and natural anthelminthics for goat nematode that is environment friendly. M. paniculata leaves has medicinal properties in the treatment of relieving colic, diarrhea, dysentery and flatulence (Thinkhaonoi, 2009). It was found that water extracts of $M$. paniculata leaves affected killing of parasite Stellantchasmus falcatus and
Haplorchis taichui. Boonkusol (2017) reported that both crude extracts from Tamarindus indica seeds and Murraya paniculata leaves showed 100\% larval mortality after in vitro $12 \mathrm{~h}$ incubation. According to $\mathrm{Wu}$ et al. (2016) report, three flavonoids in glass-leaf extract exhibited anti-inflammatory activity in white blood cells and gastrointestinal mucosal cells, reducing the formation of nitric oxide and Interleukin-6. Phytochemicals in the two plants like flavonoids and oleanane type triterpenes may have had their independent or synergistic anthelmintic effects (Zafar et al., 2009).

Study of the substance in M. paniculata leaf showed that it contains 70 polymethoxylated flavonoids (PMFs), including 45 flavonoids, 17 flavonoids and 8 types of PMFs (Zhang et al., 2011). In addition, E-caryophyllene, Spathulenol and Delta-elemene were found. These substances exhibited significant anti-inflammatory property (Lv et al., 2013). Rodanant et al. (2015) reported that ethyl acetate extract of $M$. paniculata leaf contained coumarins, Murrangatin, Murrangatin acetate, Murranganonesenecionate, Micropubescin and Tetramethoxyflavone which have anti-inflammatory effect. In addition to $M$. paniculata leaves, there are also reports of important substances derived from its branches that contained 39 species of PMFs, including 24 flavonoids, 10 flavonoids and five types of PMFs glycosides and these compounds are resistant to inflammation (Zhang et al., 2013).

In the last decades, the application of naturally biological substances acquired from plants with medicinal activities is benefiting importance in human health. There are presently, a number of plants extracts that have been commercialized worldwide (Pyakuryal, 2012). Similarly, plants and their derivatives are being profoundly researched for efficacy against animal parasites. Several plants are currently being investigated to identify available anthelmintic agents for using in animals (Aguilar et al., 2008; Shai et al., 2009; AlonsoDíaz et al., 2010). Soro et al. (2013) also reported anthelmintic efficacy of Anogeissus leiocarpus Guill \& Perr (Combretaceae) and improvement of body weight after in vivo treatment in sheep. M. paniculata, an important 
medicinal plant in Thailand, showed presently a significant fecal egg reduction and an increase in body weight in the $M$. paniculata treated goats. This finding could be an alternative mean for sustainable solving problems of high anthelmintic cost, resistance to anthelmintics and chemical residues in meat and milk for human consumption.

Blood glucose levels indicate the state of energy balance in the body of the animal ((Plumb, 1999). If there is enough energy consumption from food, blood glucose is in standard level. Blood urea is variable throughout the day, depending on several factors such as the protein level, protein degradation in the body proteolysis) during fasting and excess amino acids which were converted into urea (Lewis, 1957). In this study, urea levels were slightly higher than standard range (19.93 to $28.60 \mathrm{mmol} / \mathrm{l})$. This may be due to excess consumption of diets protein. In addition, the present results demonstrated that the proportion of albumin to globulins in blood was not different among groups. The ratio of albumin to globulin is a measure of the health of animals by the protein globulin, which is involved. If higher levels of globulin are present, it is possible to diagnose primarily that animals have a pathogenic or parasitic infection. Diagnosis should be made in conjunction with other hematologic values, such as eosinophils are specific to the diagnosis of peritonitis (Shelly, 1997).

\section{Conclusion}

The feeding of M. paniculata leaves demonstrated significantly higher in vivo anthelmintic activity and change of body weight than untreated goats, without affecting on haematological parameters, glucose, total protein, urea, albumin and globulin of goats. Compound analysis of $M$. paniculata leaves revealed that M. paniculata leaves contained higher protein content than grass and the protein content was closed to the meal concentrate.

\section{Acknowledgement}

This research was granted by the National Research Council of Thailand (2560A13102004; 6/2560). A special gratitude to farmers who provide experimental goats in this study.

\section{Author's Contributions}

Duangjai Boonkusol: Designed research study, conducted research, compiled the literary review, analyzed and interpreted the study findings, drew conclusions, contributed manuscript preparation.

Janejira Detraksa: Conducted research, analyzed and interpreted the results.

Kansuda Duangsrikaew: Conducted research, compiled the literary review.

Wuttipong Tongbai: Coordinated the implementation of research work. All authors have read and approved the manuscript.

\section{Conflict of Interest}

All authors confirm that this article is original and there is no conflict of interest in this article to declare.

\section{References}

Aguilar, H.H. de PM Gives, D.O. Sánchez, M.E. Arellano and E.L. Hernández et al., 2008. In vitro nematicidal activity of plant extracts of the Mexican flora against Haemonchus contortus fourth larval stage. Annals New York Academy Sci., 1149: 158-60. DOI: 10.1016/j.vetpar20011.02.019

Alonso-Díaz, M.A., J.F.J. Torres-Acosta, C.A. Sandoval-Castro and H. Hoste, 2010. Tannins in tropical tree fodders fed to small ruminants: A friendly foe. Small Ruminant Res. 89: 164-73. DOI: 10.1016/j.smallrumres.2009.12.040

AOAC, 1990. Official Method of Analysis. 15th Edn., Association of Official Agricultural Chemists, Inc., Virginia. ISBN-10: 0-935584-42-0, pp: 309.

Boonkusol, D., 2016. Prevalence of gastrointestinal parasites in goats in Lopburi province, Thailand. Academic J. Uttaradit Rajabhat University, 11: 14-23.

Boonkusol, D., 2017. Effects of herb extracts on mortality of goat strongyles larva. Prawarun Agric. J., 14: 208-216.

Burke, J.M., A. Wells, P. Casey and Kaplan, 2009. Herbal dewormer fails to control gastrointestinal nematodes in goats. Vet. Parasitology, 160: 168-70. DOI: $10.1016 /$ j.vetpar.2008.10.080

Dawo, F. and M. Tibbo, 2005. Anthelmintic effect of Halothamus somalensis in Arsi-Bale goats. Livestock Res. Rural Development, 17: 1-6.

Deore, S.L. and S.S. Khadabadi, 2010. In vitro anthelmintic studies of Chlorophytum borivilianum Sant. and Fernandez tubers. Indian J. Natural Products Resources, 1: 53-56.

Eguale, T., D. Tadesse and M. Giday, 2011. In vitro anthelmintic activity of crude extracts of five medicinal plants against egg hatching and larval development of Haemonchus contortus. J. Ethnopharmacology, 137: 108-113. DOI: $10.1016 /$ j.jep.2011.04.063

Githiori, J.B., S. Athanasiadou and S.M. Thamsborg, 2006. Use of plants in novel approaches for control of gastrointestinal helminths in livestock with emphasis on small ruminants. Vet. Parasitology, 139: 308-320. DOI: 10.1016/j.vetper.2006.04.021

Jabbar, A., M.A. Zaman, Z. Iqbal, M. Yaseen and A. Shamim, 2007. Anthelmintic activity of Chenopodium album (L.) and Caesalpinia crista (L.) against trichostrongylid nematodes of sheep. J. Ethnopharmacology, 114: 86-91. DOI: 10.1016/j.jep.2007.07.027 
Kochapakdee, S., W. Pralomkarn, S. Choldumrongkul, S. Saithanoo and B.W. Norton, 1991. Prevalence of internal parasite in Thai native female goats. Proceedings of International Seminar held in Hat Yai, Thailand, Goat Production in the Asian Humid Tropics, pp: 206-212.

DOI: 10.14202/vetworld.2016.728-734

Lewis, D., 1957. Blood urea concentration in relation to protein utilization in the ruminant. J. Agric. ScienceCambridge, 48: 438-442.

DOI: $10.1017 / \mathrm{s} 0021859600032962$

Lv, H.N., X.Y. Guo, P.F. Tu and Y. Jiang, 2013. Comparative analysis of the essential oil composition of Murraya paniculata and M. exotica. Natural Product Communications, 8: 1473-1475. PMID: 24354205

Plumb, D.C., 1999. Veterinary Drug Handbook. Iowa State University Press.

Pyakuryal, B.A., 2012. Feasibility study on the application of green technology for sustainable agriculture development: Assessing the policy impact in selected member countries of ESCAPAPCAEM. United Nations. pp: 117.

Rodanant, P., P. Khetkam, A. Suksamrarn and J. Kuvatanasuchati, 2015. Coumarins and flavonoid from Murraya paniculata (L.) Jack: Antibacterial and antiinflammation activity. Pakistan J. Pharmaceutical Sci., 28: 1947-1951. PMID: 26639491

Shai, L.J., E.S. Bizimenyera, V. Bagla, L.J. McGaw and J.N. Eloff, 2009. Curtisia dentate (Cornaceae) leaf extracts and isolated compounds inhibit motility of parasitic and free-living nematodes. Onderstepoort J. Vet. Res., 76: 249-56. PMID: 20698444

Soro, D., W.M. Koné, B. Bonfoh, B. Dro and K.B. Toily et al., 2013. In vivo anthelmintic activity of Anogeissus leiocarpus Guill \& Perr (Combretaceae) against nematodes in naturally infected sheep. Parasitology Research, 112: 2681-2688.

DOI: $10.1017 / \mathrm{s} 00436-013-3435-y$

Thinkhaonoi, S., 2009. Thai Wisdom, Herbs for Animals. Neon Book Media Bangkok. ISBN-10: 9786119001688 , pp: 96.
Van Soest, P.J., 1987. Nutritional Ecology of Ruminant. 2nd Edn., Cornell University Press, Ithaca, New York. ISBN-13: 978-0801427725, pp: 373.

Waller, P.J., 2006. From discovery to development: current industry perspectives for the development of novel methods of helminth control in livestock. Vet. Parasitology, 139: 1-14. DOI: 10.1016/j.vetpar.2006.02.036

Waller, P.J., G. Bernes, S.M. Thamsborg, A. Sukura and S.H. Richter et al., 2001. Plants as de-worming agents of livestock in the Nordic countries: Historical perspective, popular beliefs and prospects for the future. Acta Veterinaria Scandinavica, 42: 31-44. DOI:10.1186/1751-0147-42-31

$\mathrm{Wu}$, J., K. Liu and X. Shi, 2016. The anti-inflammatory activity of several flavonoids isolated from Murraya paniculata on murine macrophage cell line and gastric epithelial cell (GES-1). Pharmacology Biology, 5: 868-881. DOI: $10.3109 / 13880209.2015 .1089294$

Zafar, I., H.A. Bachaya, M.K. Nisar, A. Jabbar and A.H. Gilani et al., 2009. In vitro and in vivo anthelmintic activity of Terminalia arjuna bark. Int. J. Agriculture Biol., 11: 273-278.

Zhang, J.Y., J.Q. Lu, X.Y. Gao, Q. Zhang and N. Li et al., 2013. Characterization of thirty-nine polymethoxylated flavonoids (PMFs) in the branches of Murraya paniculata by HPLC-DAD-ESI-MS/MS. Chinese J. Natural Medicines, 11: 63-70. DOI: 10.1016/s1875-5364(13)6009-6

Zhang, J.Y., N. Li, Y.Y. Che, Y. Zhang and S.X. Liang et al., 2011. Characterization of seventy polymethoxylated flavonoids (PMFs) in the leaves of Murraya paniculata by on-line hing-performance liquid chromatography coupled to photo diode array detection and electrospray tandem mass spectrometry. J. Pharmaceutical Biomedical Analysis, 56: 950-961.

DOI: 10.1016/j.jpba.2011.08.019 